\title{
Coregulation of NADPH Oxidase Activation and Phosphorylation of a 48-kD Protein(s) by a Cytosolic Factor Defective in Autosomal Recessive Chronic Granulomatous Disease
}

Susan E. Caldwell, Charles E. McCall, Cynthia L. Hendricks, Peter A. Leone, David A. Bass, and Linda C. McPhail

Departments of Biochemistry and Medicine, Bowman Gray School of Medicine of Wake Forest University,

Winston-Salem, North Carolina 27103

\begin{abstract}
The mechanisms regulating activation of the respiratory burst enzyme, NADPH oxidase, of human neutrophils (PMN) are not yet understood, but protein phosphorylation may play a role. We have utilized a defect in a cytosolic factor required for NADPH oxidase activation observed in two patients with the autosomal recessive form of chronic granulomatous disease (CGD) to examine the role of protein phosphorylation in activation of NADPH oxidase in a cell-free system.

NADPH oxidase could be activated by SDS in reconstitution mixtures of cytosolic and membrane subcellular fractions from normal PMN, and SDS also enhanced phosphorylation of at least 16 cytosolic and 14 membrane-associated proteins. However, subcellular fractions from CGD PMN plus SDS expressed little NADPH oxidase activity, and phosphorylation of a 48-kD protein(s) was selectively defective. The membrane fraction from CGD cells could be activated for NADPH oxidase when mixed with normal cytosol and phosphorylation of the 48-kD protein(s) was restored. In contrast, the membrane fraction from normal cells expressed almost no NADPH oxidase activity when mixed with CGD cytosol, and phosphorylation of the 48-kD protein(s) was again markedly decreased. Protein kinase C (PKC) activity in PMN from the two patients appeared to be normal, suggesting that a deficiency of PKC is not the cause of the defective 48-kD protein phosphorylation and that the cytosolic factor is not PKC.

These results demonstrate that the cytosolic factor required for activation of NADPH oxidase also regulates phosphorylation of a specific protein, or family of proteins, at 48 $k D$. Although the nature of this protein(s) is still unknown, it may be related to the functional and phosphorylation defects present in CGD PMN and to the activation of NADPH oxidase in the cell-free system.
\end{abstract}

\section{Introduction}

Human neutrophils (PMN) play a critical role in host defense against microorganisms and in the inflammatory response (1). One of the primary mechanisms for effecting these reactions is

Address reprint requests to Dr. McPhail, Department of Biochemistry, Bowman Gray School of Medicine of Wake Forest University, 300 S. Hawthorne Rd., Winston-Salem, NC 27103.

Published in abstract form in 1987. (Clin. Res. 35:655a.)

Received for publication 9 January 1987 and in revised form 5 October 1987.

J. Clin. Invest.

(c) The American Society for Clinical Investigation, Inc.

$0021-9738 / 88 / 05 / 1485 / 12 \$ 2.00$

Volume 81, May 1988, 1485-1496 the generation of toxic oxygen radicals by the PMN. The enzyme in PMN that triggers oxygen radical production is an activatable NADPH oxidase, whose mechanism of activation is still unknown. The active enzyme appears to be a multicomponent complex, most likely consisting of a flavoprotein and a unique low potential cytochrome, cytochrome $b_{559}(2)$.

Until recently, activation of NADPH oxidase could only be achieved by stimulation of intact PMN with a wide variety of agents, including opsonized particles, phorbol esters, chemotactic peptides, and certain detergents (2). One characteristic these stimuli share is the ability to trigger activation of protein kinases inside the cell resulting in the phosphorylation of endogenous proteins (3-8). Protein kinase $C(P K C)^{1}$ has been of particular interest as an intermediate. Direct activators of PKC, such as phorbol esters and cell-permeable diacylglycerols (9), trigger oxidase activation in the intact cell by an apparent PKC-dependent mechanism (10-13). In addition, stimuli, such as concanavalin $A$ and chemotactic peptides, induce the release of endogenous stores of diacylglycerol from membrane phospholipids and thus could activate PKC (14).

Further evidence supporting a role for protein phosphorylation in the activation of NADPH oxidase is given by recent reports of a phosphorylation defect in the PMN from several patients with chronic granulomatous disease (CGD), observed by stimulation of the intact cell (15-17). CGD is an inherited disease characterized by increased susceptibility to bacterial infection, in which the only known functional defect is the inability of their phagocytic cells to produce oxygen radicals in response to cell stimulation. Two modes of inheritance of the disease are observed, X-linked recessive and autosomal recessive $(18,19)$. Recently, the gene defect in the X-linked form has been described (20) and the gene product appears to be a subunit of the cytochrome $b_{559}(21,22)$. PMN from most patients with this form of the disease lack the characteristic spectrum of the cytochrome (23). The gene defect in the autosomal recessive form has yet to be identified. However, the phosphorylation defect in CGD has been attributed solely to the autosomal recessive form (15), although, this has been disputed $(16,24)$.

Recently, a cell-free system for activation of NADPH oxidase has been developed by ourselves (25) and others (26-28). Activation requires the apparent interaction of cytosolic and membrane cellular cofactors and can be achieved by the addition of an amphiphile, either arachidonic acid or SDS (29), to the isolated cell fractions. The identities of the cytosolic and membrane cofactors are unknown, although at least one nec-

1. Abbreviations used in this paper: $\mathrm{CB}$, cytochalasin $\mathrm{B}$; CGD, chronic granulomatous disease; DFP, diisopropylfluorophosphate; EP, extractable particulate fraction; NEP, nonextractable particulate fraction; PKC, protein kinase C; PMA, phorbol myristate acetate. 
essary membrane component is cytochrome $b_{559}(30)$. In addition, a recent abstract reports that the cytosolic factor activity is absent in a CGD patient with the autosomal recessive form (31).

It is not yet clear if a protein kinase is involved in oxidase activation in this system. Arachidonate can activate PKC (32), but inhibition or depletion of PKC does not block arachidonate-mediated activation of NADPH oxidase in the cell-free system $(30,33,34)$. Contradictory reports as to the requirement for ATP in the system have appeared $(30,35)$. Finally, it has not yet been determined if arachidonate or SDS can induce phosphorylation of endogenous protein substrates in conjunction with activation of NADPH oxidase in the cell-free system.

In this report, the role of protein phosphorylation in the activation of NADPH oxidase in the cell-free system is examined. Using both normal PMN and PMN lacking cytosolic factor activity from patients with the autosomal recessive form of CGD, we have compared the ability of SDS to induce oxidase activation and phosphorylation of endogenous proteins in cell-free mixtures of cytosolic and membrane fractions. Results suggest that the cytosolic factor required for NADPH oxidase activation in the cell-free system is also specifically required for the SDS-dependent phosphorylation of a 48-kD protein, or family of proteins.

\section{Methods}

Isolation of cells. PMN ( $>95 \%$ purity) were purified from human peripheral blood by dextran sedimentation, Ficoll-Hypaque centrifugation, and hypotonic lysis as described (36). Two patients with autosomal recessive CGD were studied, one of which (S.S.) is a 27 -yr-old male reported previously (37). The other (S.H.) is a 25-yr-old female patient of Dr. Michael Cohen (University of North Carolina School of Medicine, Chapel Hill, NC) and was diagnosed based on clinical history and neutrophil oxidative functional studies (defective in vitro bactericidal activity and the absence of a luminol-dependent chemiluminescence response to phorbol myristate acetate, PMA, or opsonized zymosan).
Subcellular fractionation. Purified PMN were suspended at $5 \times 10^{7}$ $\mathrm{PMN} / \mathrm{ml}$ in Hanks' balanced salt solution containing $4.2 \mathrm{mM}$ sodium bicarbonate and $10 \mathrm{mM}$ Hepes, pH 7.4 (HBSS). To inhibit proteolysis (38), cells were treated with $2 \mathrm{mM}$ diisopropylfluorophosphate (DFP) for $5 \mathrm{~min}$ at $4^{\circ} \mathrm{C}$, and then washed with a 15 -fold volume of ice-cold HBSS. PMN were resuspended at $1 \times 10^{8} / \mathrm{ml}$ in a sonication buffer containing $0.34 \mathrm{M}(11 \%$, wt/vol) sucrose, $10 \mathrm{mM}$ Hepes, $1 \mathrm{mM}$ EGTA, $1 \mathrm{mM} \mathrm{NaN}_{3}, 130 \mathrm{mM} \mathrm{NaCl}, 100 \mathrm{mM} \mathrm{NaF}$, and $10 \mathrm{mM}$ sodium pyrophosphate. In some experiments, in which NADPH oxidase activity only was measured, the DFP treatment was omitted, $0.5 \mathrm{mM}$ PMSF was included, and $\mathrm{NaF}$ and pyrophosphate were omitted. These alterations had no effect on the final oxidase activity obtained. 1-ml aliquots of cells were sonicated in 5-s bursts in a melting ice bath with a setting of 1.5 using a sonicator (model W-220; Heat Systems-Ultrasonics, Inc., Farmingdale, NY) equipped with a stepped microtip. Cell breakage of $\sim 90 \%$ was achieved as monitored by phase microscopy.

Sonicates were centrifuged at $800 \mathrm{~g}$ for $10 \mathrm{~min}$ at $4^{\circ} \mathrm{C}$ to pellet unbroken cells and nuclei. Supernatants were fractionated by discontinuous sucrose density gradient centrifugation. In the first experiment, supernatants in the $11 \%$ sucrose buffer were layered over $40 \%$ (wt/vol) sucrose in a ratio of 2:1 ( $\mathrm{vol} / \mathrm{vol})$, as described by Gabig et al. (39). In subsequent experiments, a $15 \%$ (wt/vol) sucrose interface layer was included to more easily separate membrane and cytosolic fractions (40), the final ratio being $2: 1: 1$ (vol/vol) of 11,15 , and $40 \%$, respectively. Gradients were centrifuged at $4^{\circ} \mathrm{C}$ (SW 60.1 rotor; Beckman Instruments, Inc., Palo Alto, CA) at $150,000 \mathrm{~g}$ for $30 \mathrm{~min}$ (39). After centrifugation, the top layer of each discontinuous gradient (crude cytosol) was collected and centrifuged again at $150,000 \mathrm{~g}$ in a Beckman Type 50 rotor for $60 \mathrm{~min}$ at $4^{\circ} \mathrm{C}$ to pellet any contaminating particulate material (cleared cytosol). The white band at the $11 \% / 40 \%$ or the $15 \% / 40 \%$ interface from each discontinuous gradient and most of the $40 \%$ sucrose layer was collected (membrane fraction). The discontinuous gradients also yielded granule fractions as pellets, which were resuspended in sonication buffer to the original volume layered onto the gradient. All fractions were either used immediately or stored at $-70^{\circ} \mathrm{C}$.

Gradient fractions were analyzed for purity by measuring the distribution of the following marker enzymes: lactic dehydrogenase (LDH; 41) for cytosol, alkaline phosphatase (42) for plasma membrane, vitamin $B_{12}$-binding protein (43) for specific granules, lysozyme (44) for both specific and azurophil granules, and myeloperoxidase (MPO; 45) for azurophil granules. Table I summarizes the distribution

Table I. Subcellular Marker Enzyme Distribution in Fractions Isolated by Discontinuous Sucrose Gradient Fractionation

\begin{tabular}{|c|c|c|c|c|c|}
\hline \multirow[b]{2}{*}{ Fraction assayed $^{\ddagger}$} & \multicolumn{5}{|c|}{$\%$ Distribution of enzyme* } \\
\hline & LDH & $\begin{array}{c}\text { Alkaline } \\
\text { phosphatase }\end{array}$ & $\begin{array}{c}\mathbf{B}_{12} \text {-binding } \\
\text { protein }\end{array}$ & Lysozyme & MPO \\
\hline \multicolumn{6}{|l|}{$11 \% / 40 \%$ gradient } \\
\hline Cytosolic & 95.9 & 0.9 & ND & 0 & 7.1 \\
\hline Membrane & 2.5 & 93.8 & ND & 8.7 & 3.7 \\
\hline Granule & 2.0 & 5.3 & ND & 91.3 & 89.2 \\
\hline \multicolumn{6}{|c|}{$11 \% / 15 \% / 40 \%$ gradient } \\
\hline Cytosolic & 86.7 & 1.1 & 2.4 & 5.3 & 2.9 \\
\hline $15 \%$ layer & 8.3 & 7.3 & 0.4 & 0.1 & 0.4 \\
\hline Membrane & 1.4 & 83.2 & 12.1 & 8.2 & 3.7 \\
\hline Granule & 0.6 & 5.6 & 85.1 & 86.3 & 92.7 \\
\hline
\end{tabular}

* Marker enzyme levels were determined in subcellular fractions as described in Methods. Numbers given are the percentage of total activity recovered in each fraction for one experiment with the $11 \% / 40 \%$ gradient and the mean of two experiments with the $11 \% / 15 \% / 40 \%$ gradient. In the $11 \% / 15 \% / 40 \%$ gradient, total recovery for each marker (mean of two experiments) was: LDH, $85.7 \%$; alkaline phosphatase, $97.4 \%$; vitamin $\mathrm{B}_{12}$-binding protein, $79.9 \%$; lysozyme, $102.9 \%$; MPO, 68.2\%; and protein (46), 87.3\%. Distribution of protein in the $11 \% / 40 \%$ gradient was: cytosolic, $50.4 \%$; membrane, $7.5 \%$; and granule, $42.2 \%$. Protein distribution in the $11 \% / 15 \% / 40 \%$ gradient was: cytosolic, $43.8 \%$; $15 \%$ layer, $5.3 \%$; membrane, $7.8 \%$; and granule, $41.4 \%$. ${ }^{\ddagger}$ Normal PMN were sonicated and fractionated by either an $11 \% / 40 \%$ or an $11 \% / 15 \% / 40 \%$ discontinuous sucrose gradient as described in Methods. Fractions were assayed immediately for $\mathrm{LDH}$ and stored at $-70^{\circ} \mathrm{C}$ before the remainder of the marker enzyme assays. 
of these markers. In one experiment with the $11 \% / 40 \%$ gradient, the cleared cytosol fraction contained $95.9 \%$ of the recovered LDH, $0.9 \%$ of alkaline phosphatase, and a mean of $3.5 \%$ of lysozyme and MPO. The membrane fraction contained $93.8 \%$ of the recovered alkaline phosphatase, $2.5 \%$ of LDH, $8.7 \%$ of lysozyme, and $3.7 \%$ of MPO. In the $11 \% / 15 \% / 40 \%$ gradient procedure, the cleared cytosol contained $86.7 \%$ of the recovered LDH, $1.1 \%$ of alkaline phosphatase, $2.4 \%$ of $\mathrm{B}_{12}$-binding protein, $5.3 \%$ of lysozyme, and $2.0 \%$ of MPO. The membrane fraction contained $83.2 \%$ of the recovered alkaline phosphatase, $1.4 \%$ of $\mathrm{LDH}, 12.1 \%$ of $\mathrm{B}_{12}$-binding protein, $8.2 \%$ of lysozyme, and $3.7 \%$ of MPO. The granule fractions from both gradient procedures contained $>85 \%$ of the recovered granule enzyme markers. The discontinuous sucrose gradient fractionation procedure, therefore, was considered to yield cytosolic and membrane fractions of acceptable purity for use in the cell-free oxidase and phosphorylation systems.

NADPH oxidase assay in the cell-free system. Assays measured the SOD-inhibitable reduction of cytochrome $c$, and were performed as previously described $(25,36)$ with slight modifications. The assay mixture consisted of $0.048 \mathrm{mM}$ potassium phosphate ( $\mathrm{pH} 7.0$ ), 0.076 $\mathrm{mM}$ cytochrome $c$ (type III), $1.0 \mathrm{mM}$ EGTA, $10.0 \mu \mathrm{M}$ flavin adenine nucleotide (all from Sigma Chemical Co., St. Louis, MO), $7.5 \mathrm{mM}$ $\mathrm{MgCl}_{2}$, and either a 2:1 or 4:1 (vol/vol) ratio of cytosol to membrane fraction. Cell equivalence in the assay was $1.5 \times 10^{7} / \mathrm{ml}$ of cytosol and either 0.75 or $1.5 \times 10^{7} / \mathrm{ml}$ of membrane fraction. The final assay volume was $0.105 \mathrm{ml}$. Activation of NADPH oxidase was achieved by addition of $0\left(\mathrm{H}_{2} \mathrm{O}\right.$ control) to $175 \mu \mathrm{M}$ SDS (Bio-Rad Laboratories, Richmond, $\mathrm{CA}$ ) and incubation at room temperature for $4 \mathrm{~min}$. The concentration of SDS yielding optimal activation of NADPH oxidase in reconstitution mixtures of control fractions varied from 120 to 175 $\mu \mathrm{M}$ and was determined in each experiment. Equal aliquots of assay mixture were placed into two cuvettes: the reference cuvette, containing $48 \mu \mathrm{g} / \mathrm{ml}$ SOD (Diagnostic Data, Inc., Mountain View, CA), and the sample cuvette, containing $\mathrm{H}_{2} \mathrm{O}$. NADPH oxidase activity was measured by addition of $0.19 \mathrm{mM}$ NADPH to both cuvettes, and the change in absorbance at $550 \mathrm{~nm}$ recorded by a dual beam spectrophotometer (Cary 2390; Varian Instruments, Sunnyvale, CA). Initial rates were used for calculations and activity was expressed as nmol/min $/ \mathrm{mg}$ membrane protein (46) using an extinction coefficient of $21 \mathrm{mM}^{-1}$ $\mathrm{cm}^{-1}$ for cytochrome $c(47)$. Assays were performed on both fresh and frozen cell fractions with no differences in results obtained.

Assay for cytochrome $b_{559}$. The method used was a modification of published procedures $(48,49)$. PMN from normal donors and the autosomal recessive CGD patients were sonicated and fractionated by discontinuous sucrose density gradient centrifugation with sodium pyrophosphate and $\mathrm{NaF}$ omitted from, and PMSF included in, the sonication buffer. The membrane and granule fractions were analyzed for cytochrome $b_{s 59}$ content by difference spectroscopy after dithionite titration of an aerobic sample. Fractions were diluted 1:1 with $2 \mathrm{X}$ buffer, yielding final concentrations of $0.25 \mathrm{M}$ potassium phosphate (pH 7.5), $0.12 \mathrm{mM}$ sodium deoxycholate, $5.0 \mathrm{mM} \mathrm{NaN}_{3}$, and $0.5 \mathrm{mM}$ $\mathrm{H}_{2} \mathrm{O}_{2}$. The reduced minus oxidized spectrum of each diluted fraction was determined on a Cary 2390 spectrophotometer after complete reduction of the sample cuvette by $6-10 \mathrm{mM}$ anaerobically prepared dithionite. Amounts of cytochrome $b_{559}$ were expressed as pmol $/ 10^{8}$ cell equivalents using an extinction coefficient of $106 \mathrm{mM}^{-1} \mathrm{~cm}^{-1}$ at the Soret peak (49).

Cell-free protein phosphorylation. Cell-free mixtures for phosphorylation studies consisted of $1.4 \mathrm{mM} \mathrm{MgCl}_{2}, 6.0 \times 10^{7}$ cell equivalents/ $\mathrm{ml}$ each of cytosolic fraction and membrane fraction, and $51 \mu \mathrm{Ci} / \mathrm{ml}$ [ $\left.\gamma-{ }^{32} \mathrm{P}\right] \mathrm{ATP}(12.88 \mathrm{Ci} / \mathrm{mmol}$; New England Nuclear, Boston, MA). SDS at a final concentration of $460 \mu \mathrm{M}$ or an equal volume of distilled water was added and the samples were incubated $5 \mathrm{~min}$ at room temperature. The higher concentration of SDS was used to keep the ratio of SDS to cellular material similar to that used in the procedure for activation of NADPH oxidase. Reactions were stopped by adding a two-fold volume of ice-cold sonication buffer, which also reduced the viscosity of the mixtures for subsequent centrifugation. Samples were then centrifuged at $150,000 \mathrm{~g}$ for $12 \mathrm{~h}$ at $4^{\circ} \mathrm{C}$ in a Beckman Type 50 rotor. Supernatants (cytosolic fractions) were reserved and pellets (membrane fractions) were resuspended by sonication in a small volume $(<1 \mathrm{ml})$ of sonication buffer. Part of each sample (200-300 $\mu \mathrm{l})$ was solubilized in electrophoresis sample buffer (50), boiled for 2 min in a water bath, and stored for no more than $3 \mathrm{~d}$ at $-70^{\circ} \mathrm{C}$ before analysis by SDS-polyacrylamide gel electrophoresis, as described below. The remainder of each sample was frozen at $-70^{\circ} \mathrm{C}$ without solubilization; these nondenatured fractions were assayed for protein by Peterson's modification (51) of the method of Lowry et al. (46).

Endogenous protein phosphorylation in intact PMN. Cells at 1 $\times 10^{8} / \mathrm{ml}$ from a normal donor and a CGD patient (S.S.) were suspended in buffer (4) containing $6 \mathrm{mM}$ Hepes/Tris (pH 7.4), $0.15 \mathrm{M}$ $\mathrm{NaCl}, 10 \mathrm{mM}$ glucose, $5 \mathrm{mM} \mathrm{KCl}, 1 \mathrm{mM} \mathrm{MgCl}_{2}, 0.25 \mathrm{mM} \mathrm{CaCl}_{2}$, and ${ }^{32} \mathrm{P}_{\mathrm{i}}\left(1 \mathrm{mCi} / 1-2 \times 10^{8}\right.$ cells; New England Nuclear). PMN were incubated at $37^{\circ} \mathrm{C}$ for $30 \mathrm{~min}$, washed, and resuspended at $5 \times 10^{7} / \mathrm{ml}$ in the Hepes/Tris buffer without ${ }^{32} \mathrm{P}_{\mathrm{i}}$. Cells were prewarmed for $5 \mathrm{~min}$ at $37^{\circ} \mathrm{C}$ in the presence of $10^{-5} \mathrm{M}$ cytochalasin $\mathrm{B}(\mathrm{CB})$, then treated with either dimethylsulfoxide (DMSO) or $100 \mathrm{ng} / \mathrm{ml}$ PMA for $30 \mathrm{~s}$. Reactions were terminated by addition of a 15-fold excess volume of icecold incubation buffer containing 1.0 M NaF and $10 \mathrm{mM}$ EDTA. Cells were washed and then treated with DFP and sonicated as described above. Sonicates were centrifuged at $500 \mathrm{~g}$ for $10 \mathrm{~min}$ at $4^{\circ} \mathrm{C}$, and postnuclear supernatants were centrifuged at $100,000 \mathrm{~g}$ for $1 \mathrm{~h}$ at $4^{\circ} \mathrm{C}$ in a fixed angle rotor. Supernatants (cytosolic fractions) were removed and stored at $-70^{\circ} \mathrm{C}$ : one aliquot was solubilized in electrophoresis sample buffer as described above and the remainder analyzed for protein content (51).

SDS-polyacrylamide gel electrophoresis and autoradiography. Reduced, denatured samples (30-100 $\mu \mathrm{g}$ protein/lane) were electrophoresed on $8-15 \%$ gradient polyacrylamide slab gels $(1.5 \times 140 \times 320$ $\mathrm{mm}$ ) using the discontinuous buffer system of Laemmli (50). Except where noted, within each gel, equal amounts of protein were loaded onto gel lanes. After electrophoresis, gels were silver stained by the method of Wray et al. (52), photographed, and then dried between two sheets of cellophane using a slab gel dryer (model 443; Bio-Rad). Each dried gel was exposed, typically for 1-3 d, to preflashed Kodak XOmat x-ray film with a DuPont Cronex Lightning Plus intensifying screen at $-70^{\circ} \mathrm{C}(53)$ to generate autoradiograms of the radioactive phosphoproteins. Autoradiograms were scanned with a laser densitometer (UltroScan XL) and scans were analyzed by the software package (GelScan XL; LKB-Produkter AB, Bromma, Sweden).

$P K C$ assay. PKC activity and distribution in normal PMN and PMN from the patients with CGD were determined in crude subcellular fractions as previously described (10). Briefly, PMN at $5 \times 10^{7} / \mathrm{ml}$ in HBSS were exposed, in the presence of $10^{-5} \mathrm{M} \mathrm{CB}$ at $37^{\circ} \mathrm{C}$, to either solvent alone (DMSO), $10^{-6} \mathrm{M}$ fMLP, or $100 \mathrm{ng} / \mathrm{ml} \mathrm{PMA}$ for $30 \mathrm{~s}$ and reactions were terminated by addition of a 10 -fold excess of ice-cold HBSS. After centrifugation, PMN were resuspended in an extraction buffer containing $50 \mathrm{mM}$ Tris- $\mathrm{HCl}(\mathrm{pH} 7.5), 50 \mathrm{mM}$ 2-mercaptoethanol, $1 \mathrm{mM}$ PMSF, and $2 \mathrm{mM}$ EGTA. PMN were sonicated as described above, centrifuged at $500 \mathrm{~g}$, and postnuclear supernatants were centrifuged at $150,000 \mathrm{~g}$ for $90 \mathrm{~min}$. Supernatants (cytosolic fractions) were collected; pellets were resuspended by sonication in extraction buffer containing 1.0\% Triton X-100 (Sigma Chemical Co.) and centrifuged at $150,000 \mathrm{~g}$ for $90 \mathrm{~min}$. Supernatants, the extractable particulate fractions (EPs), were saved and pellets, the non-extractable particulate fractions (NEPs), were resuspended in extraction buffer containing $0.1 \%$ Triton $\mathrm{X}-100$ and saved. Fractions were stored at $0^{\circ} \mathrm{C}$ and assayed within $2 \mathrm{~d}$ of preparation.

Protein kinase assay mixtures (10) contained, in a final volume of $0.25 \mathrm{ml}: 35 \mathrm{mM}$ Tris- $\mathrm{HCl}$ (pH 7.5), $10 \mathrm{mM} \mathrm{MgCl}{ }_{2}, 160 \mu \mathrm{g} / \mathrm{ml}$ histone type H1 (type III, Sigma), $50 \mu \mathrm{M}$ ATP with $2 \times 10^{6} \mathrm{cpm}\left[\gamma^{-32} \mathrm{P}\right] \mathrm{ATP}$, $0.4 \mathrm{mM}$ EGTA, $0.2 \mathrm{mM}$ PMSF, $10 \mathrm{mM}$ 2-mercaptoethanol, $0.01 \%$ Triton X-100, and $50 \mu \mathrm{l}$ diluted subcellular fraction. Cytosolic fractions were diluted 10-fold, EP fractions 20 -fold, and NEP fractions 2-fold. Assays were performed in the presence or absence of activators (0.6 $\mathrm{mM}$ added $\mathrm{CaCl}_{2}, 20 \mu \mathrm{g} / \mathrm{ml}$ phosphatidylserine, and $2 \mu \mathrm{g} / \mathrm{ml}$ diolein) at $30^{\circ} \mathrm{C}$ for either $5 \mathrm{~min}$ (cytosolic fractions), $60 \mathrm{~min}$ (EP 
fractions), or $30 \mathrm{~min}$ (NEP fractions). Reactions were stopped with $20 \%$ (wt/vol) TCA, precipitates collected and counted, and activity was expressed as pmol ${ }^{32} \mathrm{P}$ incorporated $/ \mathrm{min}$ per $10^{7}$ cell equivalents. Previous studies in normal PMN $(10,54)$ had demonstrated that protein kinase activity in cytosolic and EP fractions was completely dependent on the presence of phosphatidylserine, with no activity above background in the presence of calcium alone. Activity in NEP fractions showed no dependence on added $\mathrm{Ca}^{2+}$ and lipids (10).

\section{Results}

Activation of NADPH oxidase in a cell-free system from normal PMN and PMN from patients with autosomal recessive $C G D$. Activation of NADPH oxidase in a cell-free system was measured using cell fractions from normal PMN and PMN from two patients with the autosomal recessive form of CGD. As shown in Table II, substantial activation of NADPH oxidase by SDS occurred using reconstitution mixtures of normal membrane and cytosolic fractions. In contrast, mixtures of CGD membrane and cytosolic fractions had very low levels of NADPH oxidase activity in the presence of SDS. If corrected for activity observed in the absence of SDS in reconstitution mixtures of normal cell fractions $\left(2.5 \pm 0.7 \mathrm{nmol} \mathrm{O}_{2}^{-} / \mathrm{min}\right.$ per mg, mean \pm SEM, $n=6$ ), oxidase activity induced in CGD reconstituted fractions was only $2.1 \%$ of the normal control. This defect in the ability to activate NADPH oxidase appeared to reside in the cytosolic fractions from the patients with CGD, since $(a)$ reconstitution mixtures of CGD cytosol with normal membrane supported very little activation of the oxidase by SDS, and $(b)$ the CGD membrane fraction in combination with normal cytosol did allow normal levels of NADPH oxidase activation to occur. The membrane fractions of the two patients showed equal ability to support NADPH oxidase activation in the presence of normal cytosol (S.H., 84\% of activity seen with paired normal membrane, $n=2$; S.S., $106 \%$ of

Table II. Deficient Cytosolic Factor for Activation of NADPH Oxidase in Two Patients with Autosomal Recessive CGD

\begin{tabular}{lc}
\hline \multicolumn{1}{c}{ Reconstitution mixture* } & NADPH oxidase activity \\
\hline & $\begin{array}{c}n m o l ~ \\
\text { membrane protein }\end{array}$ \\
Normal cytosol + normal membrane & $159.0 \pm 52.7(6)$ \\
CGD cytosol + CGD membrane & $5.8 \pm 0.4(3)$ \\
Normal cytosol + CGD membrane & $153.4 \pm 62.4(6)$ \\
CGD cytosol + normal membrane & $8.2 \pm 0.8(4)$
\end{tabular}

* Cytosolic and membrane fractions were isolated from two patients (S.S. and S.H.) with the autosomal recessive form of chronic granulomatous disease and from six normal donors as described in Methods. One fractionation with CGD (S.S) and one with a normal donor utilized the $11 \% / 40 \%$ (wt/vol) discontinuous sucrose gradient. The remaining fractionations (one with S.S., one with S.H., and five normal donors) utilized the $11 \% / 15 \% / 40 \%$ (wt/vol) gradient separation. ₹ NADPH oxidase activation was achieved by an optimal concentration of SDS $(120-175 \mu \mathrm{M})$ and activity was measured as described in Methods. Data are given as the mean \pm SEM with the number of experiments performed, each done in triplicate on a separate day, in parentheses. At $n=3$, two experiments were with S.S. fractions and one was with S.H. fractions. In all other instances involving CGD fractions, two experiments were performed with S.H. fractions and the remainder were with S.S. fractions. normal, $n=4$ ). In one experiment (not shown), an excess of CGD cytosol $\left(5.6 \times 10^{7}\right.$ cell equivalents $/ \mathrm{ml}$ versus the usual $1.5 \times 10^{7} / \mathrm{ml}$ ) was mixed with normal membrane fraction to test the possibility of a quantitative defect. The markedly decreased level of activation of NADPH oxidase was not enhanced, suggesting that the cytosolic factor is not present in decreased amounts, at least to the level of sensitivity of our detection system.

To further exclude an oxidase defect in the CGD membrane, membrane and granule fractions from both patients were examined for their content of cytochrome $b_{559}$. No cytochrome $b$ was detected in cytosolic fractions from normal PMN. The level of cytochrome $b$ in normal PMN was $495 \pm 80$ pmol $/ 10^{8}$ cells (mean $\pm \mathrm{SD}, n=7$ ) and the cytochrome was distributed such that $32 \%$ was present in the membrane fraction and $68 \%$ in the granule fraction. Both patients had normal (S.H.) or slightly elevated (S.S.) levels of cytochrome $b$ (S.H., $492 \mathrm{pmol} / 10^{8}$ cells; S.S., $757 \pm 3$ pmol $/ 10^{8}$ cells, mean $\pm S D$, $n=2$ ) and a similar distribution as a paired normal control. Taken together, these results indicate that the PMN of the two patients with autosomal recessive CGD do not have a defect in cytochrome $b_{559}$ and, instead, are defective in the cytosolic factor required for the activation of NADPH oxidase in the cell-free system.

Protein phosphorylation in the cell-free system for NADPH oxidase activation. The cell-free system for activation of NADPH oxidase was examined for protein phosphorylation changes that might correlate with oxidase activation. Reconstitution mixtures of membrane and cytosolic fractions isolated from normal PMN and the PMN of the two patients with autosomal recessive CGD were incubated with or without SDS in the presence of $\left[\gamma-{ }^{32} \mathrm{P}\right] \mathrm{ATP}$ and then subjected to ultracentrifugation to allow separate analysis of phosphoproteins in the two fractions. Representative results obtained with reseparated cytosolic fractions are shown in Fig. 1 and with reseparated membrane fractions in Fig. 2. The left panel of each figure shows the silver-stained protein pattern of the gel and the right panel shows the autoradiogram obtained from the same gel. No apparent differences in the pattern of silver-stained proteins was observed, comparing fractions obtained from the normal donor with those from the CGD patient.

As many as 24 phosphoproteins were detected in cytosolic fractions following reconstitution of normal fractions in the presence of SDS (Fig. $1 \mathrm{~B}$, lane 1 ), of which 16 were phosphorylated more intensely and 3 were dephosphorylated by the SDS treatment (compare to lane 2). An increase in phosphorylation of a 48,000-D protein(s) (arrow) was observed in cytosolic fractions from the normal reconstitution mixture by SDS treatment (lanes 1 and 2), but not in cytosolic fractions from the CGD reconstitution mixture (lanes 3 and 4). This was the only obvious phosphorylation defect observed in the cytosolic fraction from the CGD cell-free reconstitution. Crossover mixing of normal cytosol with CGD membrane fraction (lanes 5 and 6) restored the SDS-dependent phosphorylation of the $48-\mathrm{kD}$ protein(s), suggesting that any CGD membrane components participating in the phosphorylation reaction are functional. In contrast, when the CGD cytosolic fraction was mixed with normal membrane fraction (lanes 7 and 8 ), SDS induced no increase in background phosphorylation in the $48-50-\mathrm{kD}$ region of the gel. These results indicate that a cytosolic factor necessary for phosphorylation of a 48-kD phosphoprotein(s) is either defective or absent in the 


\section{A. Cytosolic Fractions-Silver Stain}

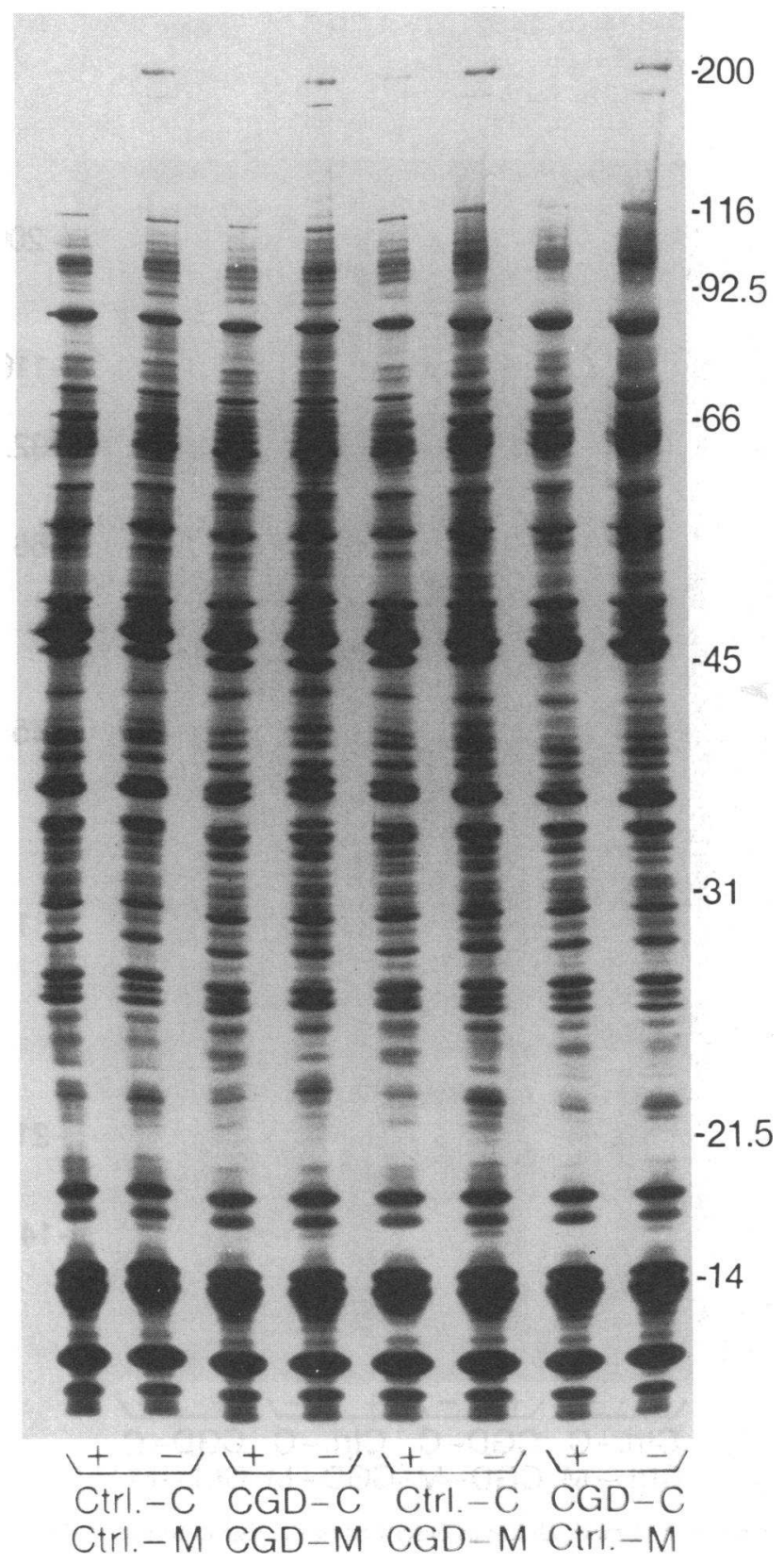

Figure 1. Phosphorylation of normal and CGD PMN cytosolic proteins in the cell-free system. PMN from a normal donor and a CGD patient (S.S.) were fractionated; cytosolic and membrane fractions were mixed with $50 \mu \mathrm{Ci}\left[\gamma^{32} \mathrm{P}\right] \mathrm{ATP}$ in the presence of $460 \mu \mathrm{M}$ SDS $(+)$ or of $\mathrm{H}_{2} \mathrm{O}$ as solvent control (-); and fractions were reseparated as described in Methods. Cytosolic fractions ( $31 \mu \mathrm{g}$ protein) were analyzed by SDS-polyacrylamide gel electrophoresis, silver staining,

CGD cytosolic fraction, or that the 48-kD phosphoprotein(s) is not present in the cytosolic fraction from the CGD PMN.

Analysis of membrane fractions, reisolated after reconstitution of normal membrane and cytosolic fractions in the presence of SDS, by SDS-polyacrylamide gel electrophoresis and autoradiography showed that $\sim 32$ phosphoproteins were present (Fig. $2 \mathrm{~B}$, lane 1 ). Of these phosphoproteins, 14 had

\section{B. Cytosolic Fractions-Autoradiogram}

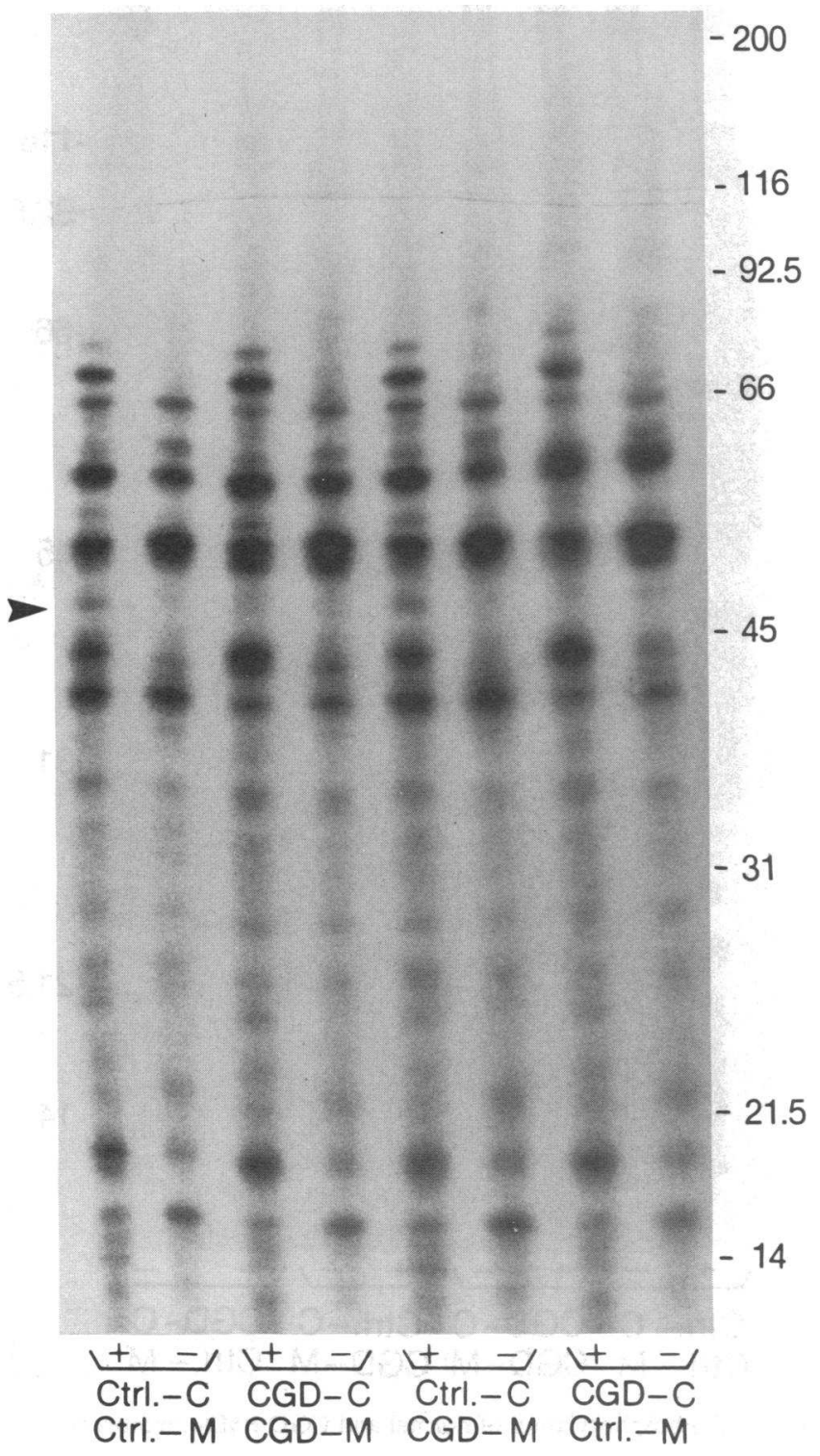

and indirect autoradiography. Ctrl.-C/Ctrl.-M, control cytosol + control membrane; CGD-C/CGD-M, CGD cytosol + CGD membrane; Ctrl.-C/CGD-M, control cytosol + CGD membrane; CGD-C/Ctrl.$\mathrm{M}, \mathrm{CGD}$ cytosol + control membrane. Arrow marks the position of the 48-kd phosphoprotein(s). Molecular weight markers are in kilodaltons. $(A)$ Silver-stained polyacrylamide gel. $(B)$ Corresponding autoradiogram.

increased phosphorylation and three had decreased phosphorylation compared with the same fraction isolated from a reconstitution mixture incubated in the absence of SDS (lane 1 vs lane 2). Analogous to the results with the cytosolic fractions, phosphorylation of a 48-kD protein(s) (arrow) was markedly enhanced by SDS treatment in the mixture of normal cytosolic and membrane fractions (lanes 1 and 2), but not during re- 


\section{A. Membrane Fractions-Silver Stain}

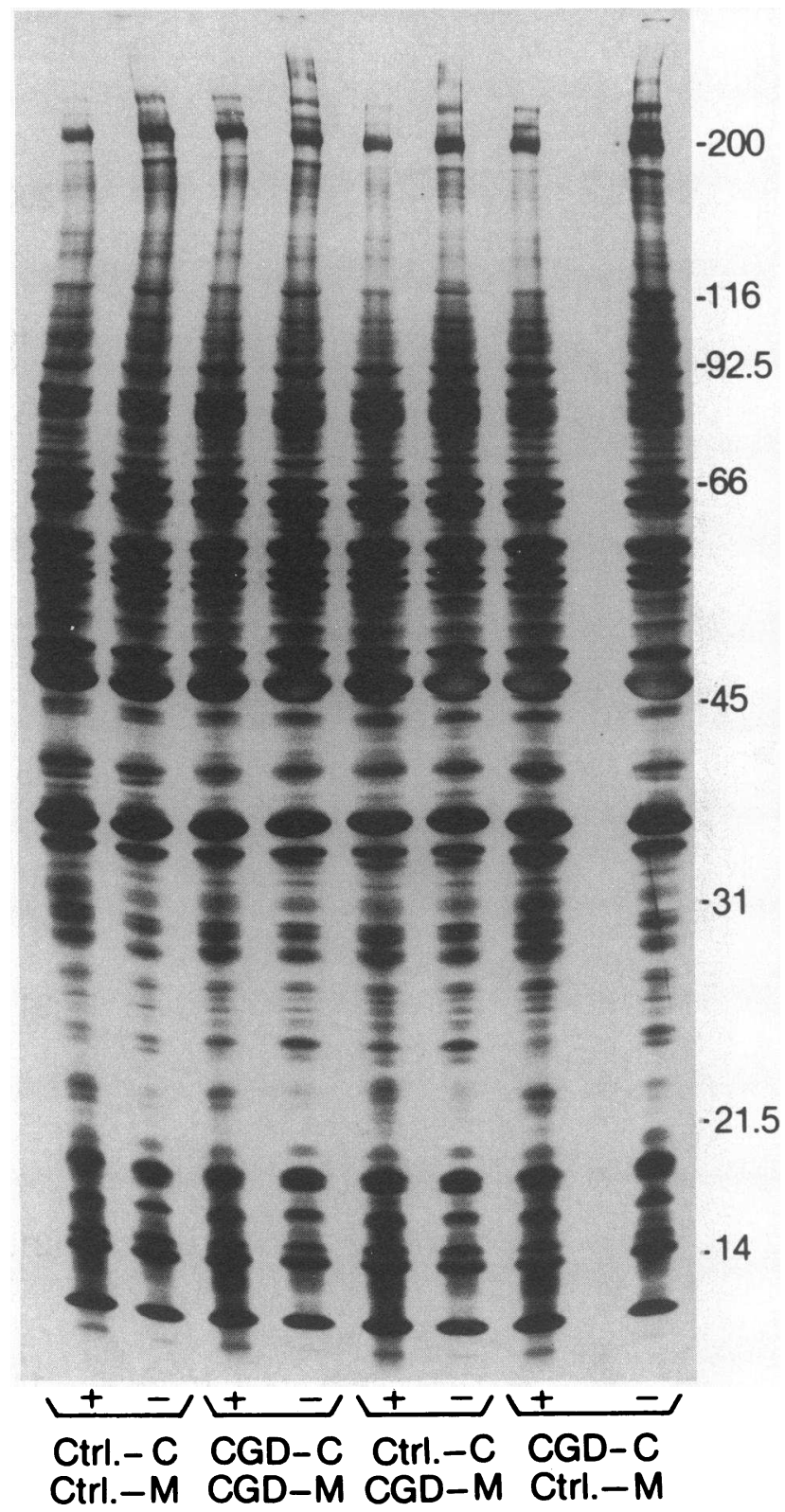

Figure 2. Phosphorylation of normal and CGD PMN membrane proteins in the cell-free system. Membrane fractions $(70.3 \mu \mathrm{g}$ protein) reseparated from cytosolic fractions in the reconstitution experiment described in Fig. 1 were analyzed by SDS-polyacrylamide gel electrophoresis, silver staining, and indirect autoradiography. Abbre-

constitution of the CGD cytosol and membrane fraction (lanes 3 and 4). Reconstitution of CGD membrane fractions with normal cytosol fully restored SDS-dependent phosphorylation of the $48-\mathrm{kD}$ phosphoprotein(s) (lanes 5 and 6 ). In contrast, minimal phosphorylation of the $48-\mathrm{kD}$ phosphoprotein(s) by SDS occurred when the CGD cytosolic fraction was reconstituted with normal membrane fraction (lanes 7 and 8), further indicating the requirement for a cytosolic component that is not functional in autosomal recessive CGD PMN.

Autoradiograms of membrane fractions from two additional cell-free reconstitution experiments, one from each pa-

\section{B. Membrane Fractions - Autoradiogram}

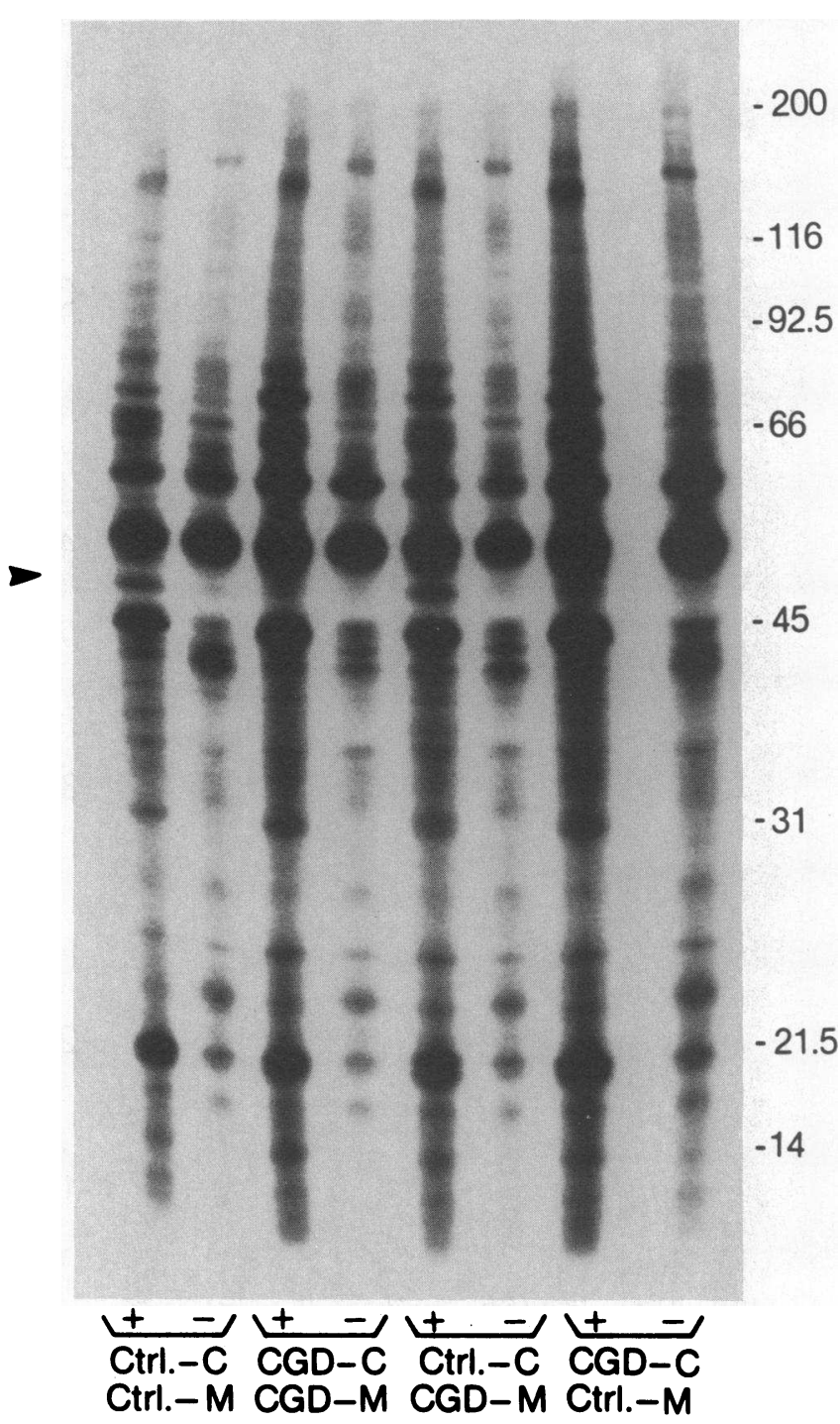

viations and methods are as described in the legend to Fig. 1. The arrow marks the position of the 48-kd phosphoprotein(s). Molecular weight markers are in kilodaltons. $(A)$ Silver-stained polyacrylamide gel. (B) Corresponding autoradiogram.

tient having autosomal recessive CGD, were subjected to densitometric analysis. Phosphoproteins in the region of $48 \mathrm{kD}$ (arrows) are shown in Fig. 3. In the presence of SDS, phosphorylation of a $48-\mathrm{kD}$ protein(s) as a result of reconstitution of normal cytosol with normal membrane fractions was observed. No phosphorylation of that protein(s) was observed during reconstitution of CGD cytosol with CGD membrane fractions in the presence of SDS. Reconstitution of normal cytosol with CGD membrane fractions and SDS restored phosphorylation of the $48-\mathrm{kD}$ protein(s). In contrast, reconstitution of CGD cytosol with normal membrane fractions and 


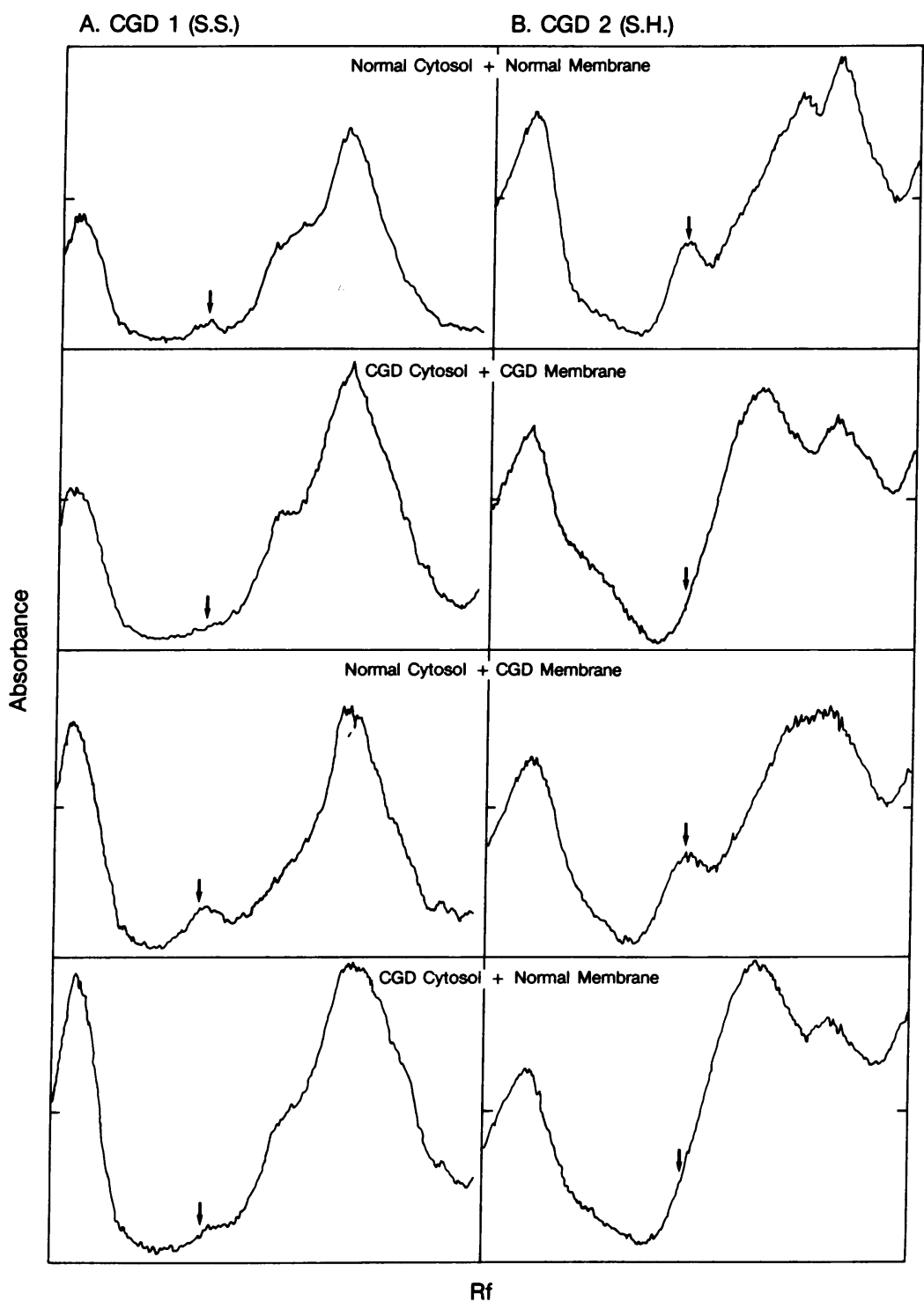

Figure 3. Densitometry scans of autoradiograms of membrane fractions from normal and CGD PMN following reconstitution with SDS in the cell-free system. Unstimulated PMN from two normal donors and two patients with autosomal recessive CGD (S.S. and S.H.) were fractionated; cytosolic and membrane fractions were reconstituted in the presence of $\left[\gamma-{ }^{32} \mathrm{P}\right]-$ ATP and $460 \mu \mathrm{M}$ SDS and reseparated as described in Methods. The experiment with S.S. is separate from the one described in Fig. 1. Membrane fractions (S.S., $100 \mu \mathrm{g}$ protein; S.H., $41 \mu \mathrm{g}$ protein) were subjected to SDS-polyacrylamide gel electrophoresis, silver-staining, and autoradiography. Autoradiograms were scanned by a soft laser densitometer in the region of the $48 \mathrm{kD}$ phosphoprotein(s) (arrows). In all scans the bottom of the gel is to the left. $(A)$ CGD 1 (S.S.). (B) CGD 2 (S.H.). (Top panels) Normal cytosol + normal membrane; (second panels) CGD cytosol + CGD membrane; (third panels) normal cytosol + CGD membrane; (bottom panels) CGD cytosol + normal membrane.
SDS resulted in minimal, or no, phosphorylation in that region of the gel.

The area under the curve at $48 \mathrm{kD}$ on the scans shown in Fig. 3 and on scans of the lanes containing fractions isolated from SDS-containing mixtures in the autoradiogram shown in Fig. 2 was determined. If the area for the reconstitution mixture of normal cytosol and CGD membrane is set at $100 \%$, the summarized data were as follows: normal cytosol + normal membrane $=75 \pm 22$; CGD cytosol + CGD membrane $=1.5 \pm 1.5 ;$ CGD cytosol + normal membrane $=14 \pm 8$ (percent, mean $\pm \mathrm{SEM}, n=3$ ). The inability of the CGD cytosol and membrane to phosphorylate the membrane-associated 48-kd protein(s), and the markedly decreased ability of the CGD cytosol to support phosphorylation when mixed with normal membrane thus was observed in three separate experiments. Taken together, these results indicate that a cytosolic factor activity necessary for SDS-dependent activation of NADPH oxidase and defective in two patients with autosomal recessive CGD, is also necessary to support SDS-dependent phosphorylation of a $48-\mathrm{kD}$ phosphoprotein(s).

Since phosphorylation of a $48-\mathrm{kD}$ protein(s) by SDS in reconstitution mixtures of normal cell fractions and the lack of phosphorylation in mixtures of CGD cell fractions was observed in both cytosolic and membrane fractions, it is possible that the same protein(s) is distributed between both fractions. Cytosolic and membrane fractions reisolated from the normal and CGD reconstitution mixtures described in Figs. 1 and 2 were analyzed on the same gel to test this possibility. The results are shown in Fig. 4. The position of the $48-\mathrm{kD}$ phosphoprotein(s) can be identified by the increase in phosphorylation induced by SDS in the normal cell fractions and the absence of that increase in the fractions from the CGD PMN. The 48-kD phosphoprotein(s) (arrow) in both cytosolic and membrane fractions comigrated (lanes 1 and 2 from left), supporting the possibility that they are the same protein or family of proteins.

It has been reported previously that neutrophils from patients with the autosomal recessive form of CGD demonstrate a defect in phosphorylation of a protein(s) in the $47-48-\mathrm{kD}$ region when intact cells are exposed to a stimulus $(15,17)$. It is thus possible that the $48-\mathrm{kD}$ protein(s) observed in our cell-free system is the same as that in the intact cell system. We tested 


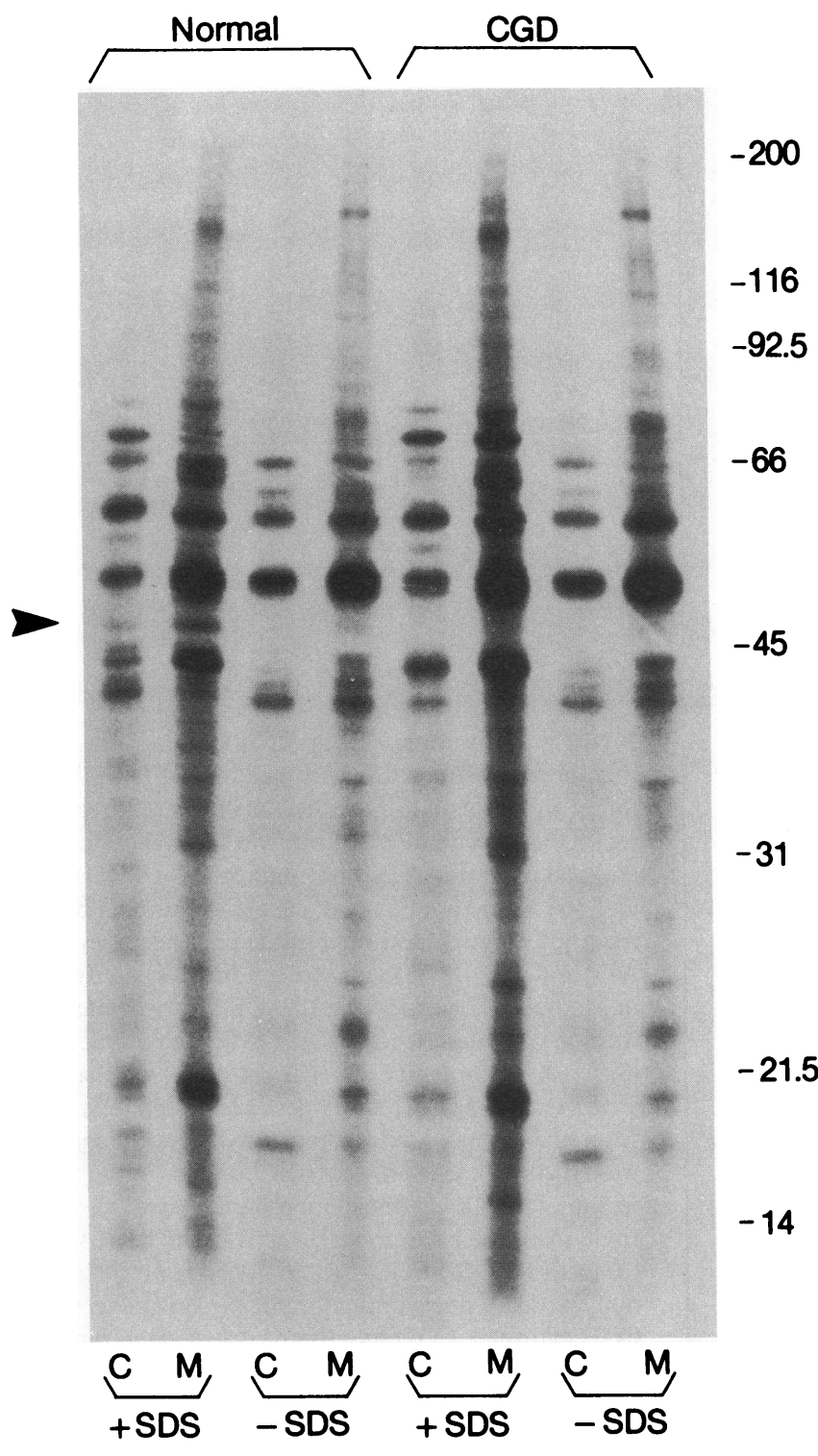

Figure 4. Comigration in SDS-polyacrylamide gel of the $\mathbf{4 8} \mathrm{kd}$ phosphoprotein(s) in both cytosolic and membrane fractions following reconstitution with SDS in the cell-free system. Cytosolic (C, $31 \mu \mathrm{g}$ protein) and membrane (M, $70 \mu \mathrm{g}$ protein) fractions from the experiment described in Fig. 1 were electrophoresed on the same polyacrylamide gel and autoradiography was performed. +SDS, fractions reconstituted in the presence of $460 \mu \mathrm{M}$ SDS; -SDS, fractions reconstituted in the presence of $\mathrm{H}_{2} \mathrm{O}$ (solvent control); Normal, PMN fractions from a normal donor; CGD, PMN fractions from a patient with autosomal recessive CGD (S.S.). Molecular weight markers are in kilodaltons. The arrow indicates the $48-\mathrm{kD}$ position.

that possibility by analyzing, in the same gel, phosphoprotein patterns of cytosolic fractions prepared from cell-free reconstitution mixtures incubated with $\left[\gamma-{ }^{32} \mathrm{P}\right] \mathrm{ATP}$ and cytosolic fractions prepared from resting or PMA-stimulated ${ }^{32} \mathrm{P}_{\mathrm{i}}$-labeled intact cells (Fig. 5). Interestingly, the phosphoprotein patterns of the cell-free versus the intact cell cytosolic fractions were quite dissimilar. However, a defect in both SDS-dependent phosphorylation of a 48-kD protein(s) (arrow) in reconstitution mixtures and in PMA-stimulated phosphorylation of a



Figure 5. Comparative phosphorylation patterns in cytosolic fractions from cell-free reconstitution mixtures and from intact normal and CGD PMN. Cytosolic fractions from the reconstitution experiment described in Fig. 1 (31 $\mu \mathrm{g}$ protein; Recon.) and from intact normal or CGD PMN that had been loaded with ${ }^{32} \mathrm{P}_{\mathrm{i}}$ and exposed to either DMSO or $100 \mathrm{ng} / \mathrm{ml}$ PMA for $30 \mathrm{~s}$ (64 $\mu \mathrm{g}$ protein; Intact) were analyzed in the same SDS-polyacrylamide gel and subjected to autoradiography. SDS, $+460 \mu \mathrm{M}$ SDS; $\mathrm{H}_{2} \mathrm{O}$, solvent control; Normal, fractions isolated from normal PMN; CGD, fractions isolated from a patient (S.S.) with autosomal recessive CGD. Molecular weight markers are in kilodaltons. Arrow marks the position of the $48-\mathrm{kD}$ phosphoprotein(s).

48-kD protein(s) was observed in cytosolic fractions from CGD cells. In addition, the $48-\mathrm{kD}$ phosphoprotein(s) in cytosolic fractions from normal reconstitution mixtures and from normal intact cells appeared to comigrate, supporting the possibility that they are the same protein(s).

$P K C$ activity in autosomal recessive CGD PMN. It was possible that the lack of phosphorylation of the $48-\mathrm{kD}$ phosphoprotein(s) and the absence of NADPH oxidase activity were due to deficient levels of PKC. The activity and distribu- 
tion of PKC were determined in crude subcellular fractions from unstimulated and stimulated PMN of normal controls and the two patients with autosomal recessive CGD. As shown in Fig. 6, the level and distribution of PKC activity in cytosolic and particulate EP and NEP fractions was similar in normal and CGD PMN, under all conditions examined. PMA stimulation of PMN from both patients with CGD induced the redistribution and loss of PKC activity similar to that observed in each paired normal control (Fig. 6, B). The effect of fMLP stimulation was examined in one patient with CGD and the normal increase in particulate-associated (EP and NEP) kinase activity was observed. These studies suggest that PKC is not defective in the two patients with CGD.

\section{Discussion}

The mechanisms that regulate NADPH oxidase, the respiratory burst enzyme in human PMN, are not yet well understood; although, progress in elucidating the nature of the en-

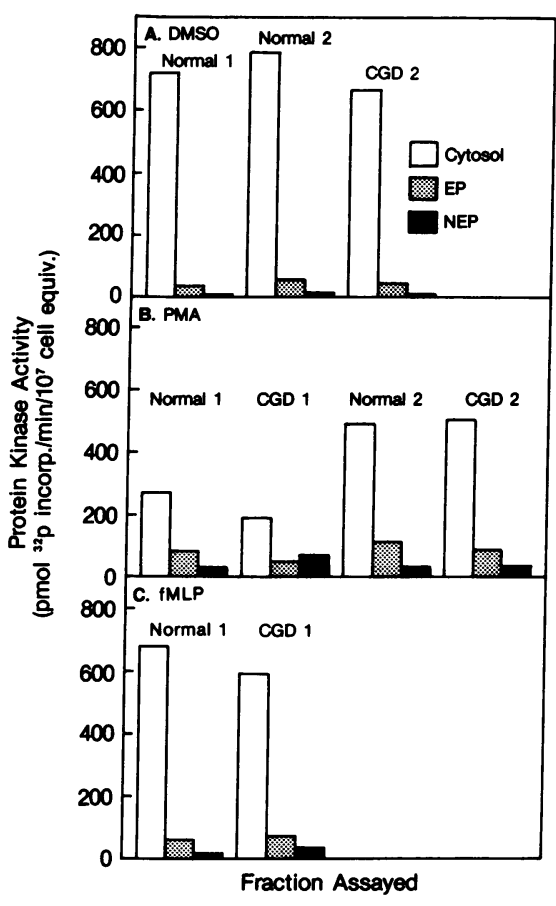

Figure 6. PKC activity and distribution in subcellular fractions from normal and CGD PMN. PKC activity was measured in subcellular fractions isolated from normal or CGD PMN that had been treated with either DMSO $(A), 100 \mathrm{ng} / \mathrm{ml}$ PMA $(B)$ or $10^{-6} \mathrm{M} \mathrm{MLP}(C)$ for $30 \mathrm{~s}$ at $37^{\circ} \mathrm{C}$ as described in Methods. Fractions assayed were the cytosolic ( $\square$, Cytosol), the detergent extract of the particulate fraction (ख, EP), and the resuspended residual particulate pellet from the detergent extract ( $\square$, NEP). Activity shown is the mean of triplicate determinations on each fraction and is given as net activity (the activity in the presence of calcium and lipids minus the activity in the absence of calcium and lipids) for the cytosolic and EP fractions and as activity in the absence of calcium and lipids for the NEP fractions (see Methods). Activity in the absence of calcium and lipids in the EP and cytosolic fractions was not different in the fractions from normal and CGD PMN and was $<91 \mathrm{pmol} / \mathrm{min}$ per $10^{7} \mathrm{PMN}$ in cytosolic and $17 \mathrm{pmol} / \mathrm{min}$ per $10^{7} \mathrm{PMN}$ in EP fractions. Two paired experiments, each with PMN from a different normal and a different patient with autosomal recessive CGD, were performed: CGD 1, S.S.; CGD 2, S.H. zyme complex at the molecular level is being made (20-22). Recently, a cell-free system for activation of NADPH oxidase was developed by us (25) and others (26-28) and can now be utilized to more directly study the mechanisms involved. Of particular interest is the role of a newly discovered cytosolic cellular cofactor required for activation of the oxidase in this system (25-28). Protein phosphorylation has been implicated as a mechanism of oxidase activation (3-17) and phosphorylation has not been directly studied in the cell-free system. Therefore, we have examined whether or not phosphorylation of endogenous proteins correlated with the cell-free activation of NADPH oxidase and have investigated the role of the cytosolic factor in the regulation of the observed phosphorylation events.

Activation of NADPH oxidase in the cell-free system correlated specifically with phosphorylation of a $48-\mathrm{kD}$ protein(s). NADPH oxidase activation was achieved by the addition of SDS to a reconstituted mixture of cytosolic and membrane fractions from unstimulated normal PMN, in agreement with previous reports in guinea pig macrophages (29) and human PMN (33), and similar to results obtained with arachidonic acid instead of SDS as the activator (25-28). SDS also induced the phosphorylation or dephosphorylation of at least 19 cytosolic and 17 membrane-associated proteins, including a 48-kD protein(s) seen in both fractions, out of $\sim 56$ phosphoproteins observed in the reconstituted cell-free system. Thus, SDS appears capable of activating a protein kinase(s), as well as either activating a phosphatase(s) or inhibiting a protein kinase(s). Although the identity of the kinase or kinases affected by SDS is not yet known, we have found that SDS can activate PKC in cytosolic fractions from human PMN as measured by exogenous histone phosphorylation (data not shown). Therefore, at least some of the phosphorylation reactions observed may be catalyzed by PKC.

Phosphorylation of the 48-kD protein(s) by SDS was markedly decreased in cell-free reconstitution mixtures of cytosolic and membrane fractions from PMN of two patients with autosomal recessive CGD. This was the only phosphorylation defect noted and it correlated with the dramatic decrease in the ability of SDS to activate NADPH oxidase in the same fractions. The defects in activation of NADPH oxidase and in phosphorylation of the $48-\mathrm{kD}$ protein(s) could both be attributed to a defect in the cytosolic fraction from the CGD PMN. The membrane fraction from CGD PMN appeared to be normal, in that it supported normal levels of both phosphorylation of the membrane-associated $48-\mathrm{kD}$ protein(s) and activation of NADPH oxidase when reconstituted with a normal cytosolic fraction. In addition, reconstitution of CGD cytosolic fraction with normal membrane fraction mimicked the defects in phosphorylation of the $48-\mathrm{kD}$ protein and in activation of NADPH oxidase seen with the reconstituted CGD fractions. Thus, the cytosolic factor required for activation of NADPH oxidase in the cell-free system is defective in PMN of two patients with the autosomal recessive form of CGD, as originally suggested by Curnutte et al. (31), and this defect correlates with defective phosphorylation of a $48-\mathrm{kD}$ protein(s).

These results clearly indicate that the cytosolic factor required for activation of NADPH oxidase also is required for phosphorylation of the $48-\mathrm{kD}$ protein(s). Our results do not differentiate between two possible explanations for the relationship between the cytosolic factor and the $48-\mathrm{kD}$ protein(s). 
The cytosolic factor could be the 48-kD phosphoprotein(s) and its presence in the membrane due to partial translocation induced by SDS. If so, then the presence of the $48-\mathrm{kD}$ phosphoprotein in the CGD membrane fraction could be caused by translocation from the normal cytosolic fraction during reconstitution. In fact, the $48-\mathrm{kD}$ protein(s) in normal membrane fractions comigrated with the $48-\mathrm{kD}$ protein(s) in normal cytosolic fractions, supporting the possibility that they are the same protein(s) and could either have dual localization or be translocated by SDS treatment. Observations consistent with the possibility that translocation of the cytosolic factor occurs are that, under conditions that prime intact normal PMN or macrophages, NADPH oxidase in membrane fractions can be activated in the cell-free system without the addition of cytosolic fractions $(25,29)$.

It is also possible that the cytosolic factor regulates phosphorylation of the $48-\mathrm{kD}$ protein(s) because the factor is itself a kinase or it activates a kinase. Our results suggest that the cytosolic factor is not PKC, since PKC activity appeared to be present at normal levels and to respond normally to stimulation by either PMA or AMLP in CGD PMN. However, we cannot exclude the possibility of a more subtle defect in PKC activity or regulation not detected by our assay procedure. That the cytosolic factor is not PKC is also supported by others using inhibitors $(33,34,55)$ or column fractionation $(30)$ to dissociate PKC activity from the oxidase activating factor in normal PMN cytosol. It is interesting that $46-48-\mathrm{kD}$ proteins in guinea pig (56) and human (57) PMN have been reported to be substrates for PKC or its catalytic subunit, although it is not yet known if these and the protein(s) observed here are the same. Further understanding of the relationship between the 48-kD protein, the cytosolic factor required for NADPH oxidase activation, and PKC or other kinases will necessitate purification of the components and more rigorous physical characterization of the $48-\mathrm{kD}$ protein or proteins.

A defect in phosphorylation of a $47-48-\mathrm{kD}$ protein, or family of proteins, in PMN from patients with CGD has been observed previously by stimulation of intact cells (15-17). Segal et al. (15), using one-dimensional polyacrylamide gel electrophoretic separation, reported that the defect was restricted to patients with the autosomal recessive form of the disease. However, Hayakawa et al. (16) and Okamura et al. (17), using two-dimensional gel electrophoresis, found that both forms of the disease expressed defects in phosphorylation of a $48-\mathrm{kD}$ family of proteins and suggested that a more pronounced defect is present in the autosomal recessive form. A third group (24), using two-dimensional gel electrophoresis, reported no defect in protein phosphorylation in six patients with CGD (presumably representing both forms of inheritance). Our results, using one-dimensional gel electrophoresis, indicate, for the first time, that a defect in phosphorylation of a 48-kD protein(s) can be observed in a cell-free system from PMN of patients with the autosomal recessive form of CGD and relate the defect to a deficient cytosolic factor required for activation of NADPH oxidase. The 48-kD protein(s) observed in our cell-free system by SDS treatment comigrated with a 48-kD protein observed by stimulating intact PMN with PMA, consistent with the possibility that the phosphorylation defect in intact CGD PMN is the same as in the cell-free system. However, further analysis by two-dimensional gel electrophoresis, peptide mapping, and phosphoamino acid determination will be necessary to fully identify and characterize the 48-kd protein(s) observed by the various groups and to determine if all groups are studying the same family of proteins.

The relationship of the phosphorylation of the $48-\mathrm{kD}$ protein(s) to the activation of NADPH oxidase in the intact cell or by SDS in the cell-free system is still not clear. Phosphorylation of a protein or proteins at $46-48 \mathrm{kD}$ has been correlated with activation of the respiratory burst in intact cells by several laboratories (8, 56-58). However, other data dissociates phosphorylation of a $48-\mathrm{kD}$ protein(s) from stimulation of oxidative metabolism (59-61). With the exception of Ohtsuka et al. (56), these studies have utilized one-dimensional gel separation systems and, if the $48-\mathrm{kD}$ region contains a family of proteins $(16,17,24)$, such discrepancies might be expected.

A requirement for a protein kinase activity in the SDS-mediated activation of NADPH oxidase in the cell-free system has not yet been demonstrated nor conclusively eliminated. Oxidase activation by SDS or arachidonate does not require exogenously added ATP $(30,35)$ and depletion of endogenous ATP has been reported by two groups to inhibit $(35,55)$ and by another to have no effect (30) on oxidase activation. PKC has been shown to activate NADPH oxidase in a cell-free system (62); however, the mechanism utilized by PKC appears to be different than that utilized by SDS and arachidonate (33) and PKC does not seem to be required for the latter compounds to exert their activating effect $(30,33,34)$. These results and our own suggest that if a kinase is involved in the SDS-activated cell-free system, it is not PKC.

Based on the present state of knowledge and the work reported here, at least three possibilities for the role of the 48-kD protein(s) in the activation of NADPH oxidase are apparent. The $48-\mathrm{kD}$ protein(s) may be unrelated to oxidase activity in PMN, but its phosphorylation may depend upon a normal cytosolic factor activity. Alternatively, the $48-\mathrm{kD}$ protein(s) may be a component(s) of NADPH oxidase; a protein of that molecular weight appears, albeit variably, in preparations of the purified oxidase flavoprotein (63). Finally, the $48-\mathrm{kD}$ protein(s) could be a regulatory molecule(s), influencing one or more of several pathways $(2,11,18,19,33,36)$ of activation of oxidative metabolism. Further efforts will be made to distinguish between these possibilities and to resolve the current discrepancies in the literature by fully characterizing the 48-kD protein(s).

\section{Acknowledgments}

We thank Sue Cousart, William Crone, and Gary Nabors for their excellent technical assistance and Susan Britt for valuable secretarial help. We especially thank Dr. Mike Cohen for providing access to his patient with autosomal recessive CGD.

This work was supported in part by National Institutes of Health grants AI-22564, AI-10732, AI-09169, AI-14929, and HL-29293.

\section{References}

1. Babior, B. M. 1978. Oxygen-dependent microbial killing by phagocytes. N. Engl. J. Med. 298:659-668.

2. McPhail, L. C., and R. Snyderman. 1984. Mechanisms of regulating the respiratory burst in leukocytes. In Regulation of Leukocyte Function. R. Snyderman, editor. Plenum Publishing Corp., New York. 247-281.

3. Schneider, C., M. Zanetti, and D. Romeo. 1981. Surface-reactive stimuli selectively increase protein phosphorylation in human neutrophils. FEBS (Fed. Eur. Biol. Soc.) Lett. 127:4-8. 
4. Andrews, P. C., and B. M. Babior. 1983. Endogenous protein phosphorylation by resting and activated human neutrophils. Blood. 61:333-340.

5. Andrews, P. C., and B. M. Babior. 1984. Phosphorylation of cytosolic proteins by resting and activated human neutrophils. Blood. 64:883-890.

6. White, J. R., C.-K. Huang, J. M. Hill, Jr., P. H. Naccache, E. L. Becker, and R. I. Sha'afi. 1984. Effect of phorbol 12-myristate 13-acetate and its analogue 4- $\alpha$-phorbol 12,13-didecanoate on protein phosphorylation and lysosomal enzyme release in rabbit neutrophils. $J$. Biol. Chem. 259:8605-8611.

7. Okamura, N., S. Ohashi, N. Nagahisa, and S. Ishibashi. 1984. Changes in protein phosphorylation in guinea pig polymorphonuclear leukocytes by treatment with membrane-perturbing agents which stimulate superoxide anion production. Arch. Biochem. Biophys. 228:270-277.

8. Pontremoli, S., E. Melloni, F. Salamino, B. Sparatore, M. Michetti, O. Sacco, and B. L. Horecker. 1986. Phosphorylation of proteins in human neutrophils activated with phorbol myristate acetate or with chemotactic factor. Arch. Biochem. Biophys. 250:23-29.

9. Nishizuka, Y. 1984. The role of protein kinase $C$ in cell surface signal transduction and tumour promotion. Nature (Lond.). 308:693698.

10. Wolfson, M., L. C. McPhail, V. N. Nasrallah, and R. Snyderman. 1985. Phorbol myristate acetate mediates redistribution of protein kinase $C$ in human neutrophils: potential role in the activation of the respiratory burst enzyme. J. Immunol. 135:2057-2062.

11. Gerard, C., L. C. McPhail, A. Marfat, N. P. Stimler-Gerard, D. A. Bass, and C. E. McCall. 1986. Role of protein kinases in stimulation of human polymorphonuclear leukocyte oxidative metabolism by various agonists. Differential effects of a novel protein kinase inhibitor. J. Clin. Invest. 77:61-65.

12. Gennaro, R., C. Florio, and D. Romeo. 1986. Co-activation of protein kinase $C$ and NADPH oxidase in the plasma membrane of neutrophil cytoplasts. Biochem. Biophys. Res. Commun. 134:305312.

13. Cox, C. C., R. W. Dougherty, B. R. Ganong, R. M. Bell, J. E. Niedel, and R. Snyderman. 1986. Differential stimulation of the respiratory burst and lysosomal enzyme secretion in human polymorphonuclear leukocytes by synthetic diacylglycerols. J. Immunol. 136:4611-4616.

14. Rider, L. G., and J. E. Niedel. 1987. Diacylglycerol accumulation and superoxide anion production in stimulated human neutrophils. J. Biol. Chem. 262:5603-5608.

15. Segal, A. W., P. G. Heyworth, S. Cockcroft, and M. M. Barrowman. 1985. Stimulated neutrophils from patients with autosomal recessive chronic granulomatous disease fail to phosphorylate a $\mathrm{M}_{\mathbf{r}}-44,000$ protein. Nature (Lond.). 316:547-549.

16. Hayakawa, T., K. Suzuki, S. Suzuki, P. C. Andrews, and B. M. Babior. 1986. A possible role for protein phosphorylation in the activation of the respiratory burst in human neutrophils. Evidence from studies with cells from patients with chronic granulomatous disease. $J$. Biol. Chem. 261:9109-9115.

17. Okamura, N., J. T. Curnutte, and B. M. Babior. 1987. Phosphoproteins and the activation of the neutrophil respiratory burst oxidase. Fed. Proc. 46:1952. (Abstr.)

18. Tauber, A. I., N. Borregaard, E. Simons, and J. Wright. 1983. Chronic granulomatous disease: a syndrome of phagocyte oxidase deficiencies. Medicine (Baltimore). 62:286-309.

19. Curnutte, J. T., and B. M. Babior. 1987. Chronic granulomatous disease. In Advances in Human Genetics. Vol. 16. H. Harris and K. Hirschhorn, editors. Plenum Publishing Corp., New York. 229-297.

20. Royer-Pokora, B., L. M. Kunkel, A. P. Monoaco, S. C. Goff, P. E. Newburger, R. L. Baehner, F. S. Cole, J. T. Curnutte, and S. H. Orkin. 1986. Cloning the gene for an inherited human disorderchronic granulomatous disease-on the basis of its chromosomal location. Nature (Lond.). 322:32-38.
21. Dinauer, M. C., S. H. Orkin, R. Brown, A. J. Jesaitis, and C. A. Parkos. 1987. The glycoprotein encoded by the X-linked chronic granulomatous disease locus is a component of the neutrophil cytochrome $b$ complex. Nature (Lond.). 327:717-720.

22. Teahan, C., P. Rowe, P. Parker, N. Totty, and A. W. Segal. 1987. The $X$-linked chronic granulomatous disease gene codes for the B-chain of cytochrome $b_{-245}$. Nature (Lond.). 327:720-721.

23. Segal, A. W., A. R. Cross, R. C. Garcia, N. Borregaard, N. H. Valerius, J. F. Soothill, and O. T. G. Jones. 1983. Absence of cytochrome $b_{-245}$ in chronic granulomatous disease. A multicenter European evaluation of its incidence and relevance. $N$. Engl. J. Med. 308:245-251.

24. Ishii, E., K. Irita, I. Fujita, K. Takeshige, M. Kobayashi, T. Usui, and K. Ueda. 1986. Protein phosphorylation of neutrophils from normal children and patients with chronic granulomatous disease. Eur. J. Pediatr. 145:22-26.

25. McPhail, L. C., P. S. Shirley, C. C. Clayton, and R. Snyderman. 1985. Activation of the respiratory burst enzyme from human neutrophils in a cell-free system. Evidence for a soluble cofactor. J. Clin. Invest. 75:1735-1739.

26. Bromberg, Y., and E. Pick. 1984. Unsaturated fatty acids stimulate NADPH-dependent superoxide production by cell-free system derived from macrophages. Cell. Immunol. 88:213-221.

27. Heyneman, R. A., and R. E. Vercauteren. 1984. Activation of a NADPH oxidase from horse polymorphonuclear leucocytes in a cellfree system. J. Leukocyte Biol. 36:751-759.

28. Curnutte, J. T. 1985. Activation of human neutrophil nicotinamide adenine dinucleotide phosphate, reduced (triphosphopyridine nucleotide, reduced) oxidase by arachidonic acid in a cell-free system. J. Clin. Invest. 75:1740-1743.

29. Bromberg, Y., and E. Pick. 1985. Activation of NADPH-dependent superoxide production in a cell-free system by sodium dodecyl sulfate. J. Biol. Chem. 260:13539-13545.

30. Curnutte, J. T., R. Kuver, and P. J. Scott. 1987. Activation of neutrophil NADPH oxidase in a cell-free system. Partial purification of components and characterization of the activation process. J. Biol. Chem. 262:5563-5569.

31. Curnutte, J. T., P. J. Scott, R. Kuver, and R. Berkow. 1986. NADPH oxidase activation cofactor (ACF): partial purification and absent activity in a patient with chronic granulomatous disease (CGD). Clin. Res. 34:455a. (Abstr.)

32. McPhail, L. C., C. C. Clayton, and R. Snyderman. 1984. A potential second messenger role for unsaturated fatty acids: activation of $\mathrm{Ca}^{2+}$-dependent protein kinase. Science (Wash. DC). 224:622-625.

33. Cox, J. A., A. Y. Jeng, P. M. Blumberg, and A. I. Tauber. 1987. Comparison of subcellular activation of the human neutrophil NADPH-oxidase by arachidonic acid, sodium dodecyl sulfate (SDS), and phorbol myristate acetate (PMA). J. Immunol. 138:1884-1888.

34. McPhail, L. C., C. L. Hendricks, M. C. Seeds, and D. A. Bass. 1986. A possible role for calmodulin in activation of the respiratory burst enzyme of human neutrophils. Clin. Res. 34:465a. (Abstr.)

35. Clark, R. A., D. G. Leidal, D. W. Pearson, and W. M. Nauseef. 1987. NADPH oxidase of human neutrophils. Subcellular localization and characterization of an arachidonate-activatable superoxide-generating system. J. Biol. Chem. 262:4065-4074.

36. McPhail, L. C., and R. Snyderman. 1983. Activation of the respiratory burst enzyme in human polymorphonuclear leukocytes by chemoattractants and other soluble stimuli. Evidence that the same oxidase is activated by different transductional mechanisms. J. Clin. Invest. 72:192-200.

37. Sanders, D. Y., M. R. Cooper, C. E. McCall, and L. R. DeChatelet. 1972. Chronic granulomatous disease of childhood with onset of symptoms at age 11 years. J. Pediatr. 80:104-106.

38. Amrein, P. C., and T. P. Stossel. 1980. Prevention of degradation of human polymorphonuclear leucocyte proteins by diisopropylfluorophosphate. Blood. 56:442-447.

39. Gabig, T. G. D. English, L. P. Akard, and M. J. Schell. 1987. Regulation of neutrophil NADPH oxidase activation in a cell-free 
system by guanine nucleotides and fluoride. Evidence for participation of a pertussis and cholera toxin-insensitive G protein. J. Biol. Chem. 262:1685-1690.

40. Huey, R., and T. E. Hugli. 1985. Characterization of a C5a receptor on human polymorphonuclear leukocytes (PMN). J. Immunol. 135:2063-2068.

41. Wroblewski, F., and J. S. LaDue. 1955. Lactic dehydrogenase activity in blood. Proc. Soc. Exp. Biol. Med. 90:210-213.

42. DeChatelet, L. R., J. V. Volk, C. E. McCall, and M. R. Cooper. 1971. Studies on leukocyte phosphatases. II. Inhibition of leukocyte alkaline phosphatase by amino acids and its reversal by zinc. Clin. Chem. 17:210-213.

43. Gottlieb, C., K. Lau, L. R. Wasserman, and V. Herbert. 1965. Rapid charcoal assay for intrinsic factor (IF), gastric juice unsaturated $B_{12}$ binding capacity, antibody to IF, and serum unsaturated $B_{12}$ binding capacity. Blood. 25:875-883.

44. Zeya, H. I., and J. K. Spitznagel. 1971. Characterization of cationic protein-bearing granules of polymorphonuclear leukocytes. Lab. Invest. 24:229-236.

45. Migler, R., and L. R. DeChatelet. 1978. Human eosinophilic peroxidase: Biochemical characterization. Biochem. Med. 19:16-26.

46. Lowry, O. H., N. J. Rosebrough, A. L. Farr, and R. J. Randall. 1951. Protein measurement with the Folin phenol reagent. J. Biol. Chem. 193:265-275.

47. Massey, V. 1959. The microestimation of succinate and the extinction coefficient of cytochrome c. Biochim. Biophys. Acta. $34: 255-256$.

48. Gabig, T. G., E. W. Schervish, and J. T. Santinga. 1982. Functional relationship of the cytochrome $b$ to the superoxide-generating oxidase of human neutrophils. J. Biol. Chem. 257:4114-4119.

49. Ohno, Y., E. S. Buescher, R. Roberts, J. A. Metcalf, and J. I. Gallin. 1986. Reevaluation of cytochrome $b$ and flavin adenine dinucleotide in neutrophils from patients with chronic granulomatous disease and description of a family with probable autosomal recessive inheritance of cytochrome b deficiency. Blood. 67:1132-1138.

50. Laemmli, U. K. 1970. Cleavage of structural proteins during assembly of the head of bacteriophage T4. Nature (Lond.). 227:680685.

51. Peterson, G. L. 1977. A simplification of the protein assay method of Lowry et al. which is more generally applicable. Anal. Biochem. 83:346-356.

52. Wray, W., T. Boulikas, V. P. Wray, and R. Hancock. 1981. Silver staining of proteins in polyacrylamide gels. Anal. Biochem. 118:197-203.
53. Laskey, R., and A. D. Mills. 1977. Enhanced autoradiographic detection of ${ }^{32} \mathrm{P}$ and ${ }^{125} \mathrm{I}$ using intensifying screens and hypersensitized film. FEBS (Fed. Eur. Biol. Soc.) Lett. 82:314-316.

54. Pike, M. C., L. Jakoi, L. C. McPhail, and R. Snyderman. 1986. Chemoattractant-mediated stimulation of the respiratory burst in human polymorphonuclear leukocytes may require appearance of protein kinase activity in the cells' particulate fraction. Blood. 67:909913.

55. Seifert, R., and G. Schultz. 1987. Fatty-acid-induced activation of NADPH oxidase in plasma membranes of human neutrophils depends on neutrophil cytosol and is potentiated by stable guanine nucleotides. Eur. J. Biochem. 162:563-569.

56. Ohtsuka, T., N. Okamura, and S. Ishibashi. 1986. Involvement of protein kinase $C$ in the phosphorylation of $46 \mathrm{kDa}$ proteins which are phosphorylated in parallel with activation of NADPH oxidase in intact guinea-pig polymorphonuclear leukocytes. Biochim. Biophys. Acta. 888:332-337.

57. Pontremoli, S., E. Melloni, M. Michetti, B. Sparatore, F. Salamino, O. Sacco, and B. L. Horecker. 1987. Phosphorylation and proteolytic modification of specific cytoskeletal proteins in human neutrophils stimulated by phorbol 12-myristate 13-acetate. Proc. Natl. Acad. Sci. USA. 84:3604-3608.

58. Heyworth, P. G., and A. W. Segal. 1986. Further evidence for the involvement of a phosphoprotein in the respiratory burst oxidase of human neutrophils. Biochem. J. 239:723-731.

59. Caldwell, S. E., D. A. Bass, L. C. McPhail, and C. E. McCall. 1987. Phosphorylation of a $48 \mathrm{kD}$ protein, defective in chronic granulomatous disease (CGD) neutrophils, is not required for activation of the respiratory burst. Fed. Proc. 46:1033. (Abstr.)

60. Sha'afi, R. I., T. F. P. Molski, and C.-K. Huang. 1987. Dissociation of the $47 \mathrm{kDa}$ protein phosphorylation from degranulation and superoxide production in neutrophils. Fed. Proc. 46:1037. (Abstr.)

61. Reibman, J., H. M. Korchak, K. A. Haines, L. B. Vosshall, and G. Weissmann. 1987. Phosphorylation of the $47 \mathrm{kDa}$ target protein is not sufficient for superoxide anion production in neutrophils. Clin. Res. 35:537a. (Abstr.)

62. Cox, J. A., A. Y. Jeng, N. A. Sharkey, P. M. Blumberg, and A. I. Tauber. 1985. Activation of the human neutrophil nicotinamide adenine dinucleotide phosphate (NADPH)-oxidase by protein kinase C. $J$. Clin. Invest. 76:1932-1938.

63. Glass, G. A., D. M. DeLisle, P. DeTogni, T. G. Gabig, B. H. Magee, M. Markert, and B. M. Babior. 1986. The respiratory burst oxidase of human neutrophils. Further studies of the purified enzyme. J. Biol. Chem. 261:13247-13251. 